Information Management and Business Review

Vol. 2, No. 6, pp. 246-251, June 2011

\title{
Monetary Shocks or Real Shocks, Which matters the most for Share Prices
}

\author{
Muhammad Imtiaz Subhani, Amber Osman \\ Iqra University Research Centre-IURC, Iqra University-IU, Karachi - Pakistan \\ amber.osman@yahoo.com
}

\begin{abstract}
This study examines that out of monetary shocks $(\Delta \mathrm{M} 2)$ and real shocks in share prices $(\Delta \mathrm{Yt}-\mathrm{k})$, which one or both really explain share prices of Karachi stock exchange 100 index. The time series econometrics is used to investigate the data for the monthly period of January 1991 to January 2011 for money supply (M2) and share prices of KSE 100 index. The results of unit root test reveal that there is a real shock in share prices and it explains the share price of KSE 100 index temporarily, while Vector auto regression revealed that Share prices of KSE 100 index is meagerly explained by the monetary shocks.
\end{abstract}

Key Words: Share Prices, Real Shocks, Monetary Shocks, Unit Root Test, Granger Causality Test

\section{Introduction}

For several years, the economic effect of the supply of money on share prices has been argued in the literature of economics. This subject has retrieved acceptance and admirations in the rouse of recent share market volatility in the United States. This unpredictability has compelled many policy makers to ponder over it since 1987 share market crash. The crash was witnessed all through world's financial markets. Credit and trade good markets experienced strong strokes in response. The crash and its stroke have lifted the question of, if moderating volatility in share prices through some ways can be possible. A dialogue has emerged concerning the mechanics of monetary policy and potential interposing actions by the State Bank Pakistan ready to foreclose a share market crisis alike to that of 1987 in US. In past researches there were numbers of variables investigated which may and may not explain the share prices of different share markets but the monetary shocks and even real shocks (i.e. the fluctuations in share prices in previous periods) won the major attention of the world that are they really explain or have any causal impact on share prices or fluctuation in share prices for current period. The main manifesto of this study is to investigate which matters the most for share prices at KSE 100 from monetary shocks and real shocks.

\section{Literature Review}

The quantity theory of money accentuates that a shift in the money supply results in a shift in the equilibrium positioning of money in relation to other assets that includes equity shares in the portfolio balance of asset holders (Dhakal \& Kandil, 1993). Dhakal, Kandil, and Sharma (1993) reasoned out that due to such shift in equilibrium positioning of money, the asset holder sets the proportion of his/her portfolios constituted by money balances and this adjustment modifies the demand for other assets that grapple with money balances, including equity shares. The raise in the money supply is anticipated to create surplus money supply balances and successively surplus demand for shares. As a result, the share prices are expected to rise and this channel of interaction between variations in the money supply and share prices has been depicted by advocators of the quantity theory of money as the direct and straight channel (Dhakal, Kandil \& Sharma, 1993).

The existence of indirect and non-straight channels of interaction and association between the money supply (M2) and share prices are also present and it concentrates on the impact and effect of changes in the money supply on such variables that channelize investors' decisions pertaining to the allocation of their portfolios options between money balances and alternative assets. A rise in the money supply produces surplus supply of money tagging a limited amount of goods and services in an economy. In prevailing rational expectations natural rate macro models, the outcome of surplus demand will affect real output and the price level in the short run with order of magnitudes that are dependent on factors defining the propensity of the short-run supply curve. In the long run, nevertheless, the absolute impact of the raise in the money supply will be 
captive or soaked up in the price level. The resulting gain in the price level may accelerate inflationary prospects in an economy, which has a positive result on the nominal interest rate. Husky nominal interest rates will affect investors' choices concerning the proportion of their portfolios to be accommodated in terms of money balances. Since, the nominal interest rate appraises the opportunity cost of holding money balances. This raise in opportunity cost will prompt asset holders to have an alternate for other financial assets, which encompasses equity shares for money in their portfolios.

Despite of the fact that direct and indirect effects of the money supply on share prices have been realized and this relationship has aroused another argument in efficient market models (Fama, 1970). The argument is primal to the definition of efficiency and its logical implication about the time of the alteration of share prices to the oscillation in the money supply. Share prices in an efficient market contemplate all publicly information present about the future profitability of firms. Other way round, the historical data are an ineffective tool in developing trading laws because such information is already contained in share prices. This connotes that past oscillation in the money supply should not be able to augur share prices. These changes are induced by observed economic disturbances that had been contemplated previously in share prices. Oscillations in the money supply are conjectured to result in change of share prices. Whether the share market is efficient, it defines the lag length of the reaction of share prices to oscillation in the money supply. One can theorize on the possibility of the relationship that is causal between share prices and the money supply. If the SBP foresees shocks in the economic system with monetary policy, then oscillation in share prices may incite SBP officials to adjust the rate of growth of the money supply. A decrease in share prices stimulated by traders' increased disposition that may be understood as a signal of a possible recession. Many discussions indicated the possibility of bidirectional or bilateral causality between share prices and money supply. A number of studies have analyzed the presence of this bidirectional/bilateral causality. The econometric methodology and the findings of the diverse studies have been deviated. Sprinkel (1964) used a graphical approach to give the instance of the relationship between oscillation in share prices and monetary growth. In distinction many used cross correlation analysis to observe the bidirectional/bilateral relationship between money supply and share returns. Other hits of this study have utilized bivariate regressions for the empirical investigation of the association between money supply and share prices (Mookerjee, 1987).

Other investigations have been implicated about various determiners of share prices which includes real output, the interest rate and expected inflation (Hashemzadah \& Taylor, 1988). All these studies, excluding the latter study have opted bivariate regressions to examine the relationship between share prices and their major determinants. But the share price involves a set of relationships that jointly explain the shocking behavior of these prices. A single estimation function may be incompatible for what is fundamentally a system of equations. Subhani and Osman (2010) also noticed that there is a relationship between share prices and Inflation (CPI) though, the relationship was negative, but it was reported that it is the investor's perception which causes discrepant effect to trading. Participant's reaction to the CPI announcements varies and results a declining trade volume variably. While, Homa and Jeffe (1971) estimated the negative relationship between the share prices and money supply and concluded that the accurate forecast of share prices is possible only because of the stable relationships between money supply and share prices, whereas, Pearce and Roley (1985) examined the effects of money supply news on share prices, and found the negative relationships between the unanticipated increase in the money supply and share prices. The time series analysis was also applied to investigate the relationships but found no causal relationship between the money supply and share prices (Kraft \& Kraft, 1977). Alatiqi and Fazel (2008) evaluated the relationships of share prices with its previous lag and investigated the non-stationarity in the share prices for which they used unit root test.

\section{Hypotheses}

H1: The share price of KSE 100 index has the unit root.

H2: The Fluctuations in share prices for previous periods explain the current fluctuations in share price of KSE 100 index.

H3: The Fluctuations in Money Supply explains the fluctuations in share price of KSE 100 index.

H4: The Money Supply causes the share price of KSE 100 index. 


\section{Research Methodology \& Econometrical Models}

To explore the non-stationarity/stationarity and shocks in the share prices and money supply and to investigate impact of these shocks on share prices the data for the monthly period of January 1991 to January 2011 for money supply (M2) and share prices of KSE 100 index are taken from the publically available sources (websites of State Bank of Pakistan and Karachi Stock Exchange). Several econometrical Models are used to investigate the all formulated research hypotheses. For testing the unit root in the data of Share prices of KSE 100 index i.e H1, when Share Prices (Y) is trended, the unit root test is applied but vector auto regression is also used to justify the application of unit root test. Following is the econometrical equation for unit root test for the series of Share prices:

$$
\Delta Y t=\alpha Y t-1+x^{\prime} t+\beta 1 \Delta Y t-1+\ldots \ldots . . \beta p \Delta Y t-p+E T t \quad \text { Equation } 1
$$

The following vector auto regression model is used to test the hypotheses $\mathrm{H} 2$ and $\mathrm{H} 3$ :

$$
\Delta Y t=C+\beta 1 \Delta M 2 t-1+\beta 2 \Delta M 2 t-2+\beta 3 \Delta Y t-1+\beta 4 \Delta Y t-2+E T t \quad \text { Equation } 2
$$

Where, $\mathrm{Y}=$ Share prices of KSE 100 index and M2= Money Supply

Moreover, to check the causality, the Bivariate Granger causality test is also applied on both of the series of share prices and money supply to investigate that whether the past values of M2 are useful for predicting Share Prices (causal relationship i.e. H4), once Share Prices history has been modeled.

\section{Results}

Findings of Unit Root Test:

\begin{tabular}{|c|c|c|c|c|c|c|c|}
\hline \multirow[t]{2}{*}{ At Level } & & \multicolumn{5}{|c|}{ At 1 ${ }^{\text {st }}$ Difference } & \multirow[b]{2}{*}{ Prob.* } \\
\hline & & t-Statistic & Prob.* & & & t-Statistic & \\
\hline ADF test & & -1.133768 & 0.7027 & ADF test & & -9.617480 & 0.0000 \\
\hline Test Critical & $1 \%$ level & -3.457984 & & Test Critical & $1 \%$ level & -3.457984 & \\
\hline & $5 \%$ level & -2.873596 & & & $5 \%$ level & -2.873596 & \\
\hline & $10 \%$ level & -2.573270 & & & $10 \%$ level & -2.573270 & \\
\hline
\end{tabular}

Table 1: Null Hypothesis: Share prices of KSE 100 INDEX has a unit root

The primary focus of this study is to investigate the stationary levels of share prices. For this purpose ADF unit root test is applied to examine the stationarity at level and Ist difference. The empirical findings are reported in the table 1 which reveals that at level the ADF statistic value is -1.1337 and the associated onesided p-value (for a test with 236 Observations) is 0.7027. In addition, EViews reports the critical values at the $1 \%, 5 \%$ and $10 \%$ levels. Notice here that the t $\alpha$ statistic value is greater than the critical values so that we do not reject the null at conventional test sizes means that the Share prices of KSE 100 index has a unit root.

$$
\begin{array}{ccc}
\Delta Y t=\alpha Y t-1+ & x^{\prime} t+ & \beta 1 \Delta Y t-1+E T t \\
-0.00963 & 1.562 & 0.382941 \\
{[-1.1337]} & {[1.4066]} & {[5.91420]}
\end{array}
$$

Equation 3

In the above equation 3 , xt is optional exogenous regressors which is comprised on constant in the above equation, the $\alpha$ and $\beta 1$ are the parameters of Yt- 1 and $\Delta \mathrm{Yt}-1$, which are estimated -0.00963 and 0.382941 respectively, the $t$ value (5.91420) in the parentheses for $\beta 1$ explains that the change in Yt- 1 explains significantly to change in Yt. As it can be seen that $\alpha<1$ (i.e. $\alpha=-0.00963$ at $t=-1.1337>$ critical values) means that the Share prices of KSE 100 index has an unit root and hence the series is a non- stationary series at level. While at the $1^{\text {st }}$ difference the ADF test statistic is -9.617480 and the associated one-sided p-value is 0.000 . which implies that the t $\alpha$ statistic value is lesser than the critical values so that we do not accept the 
null hypothesis means that the Share prices of KSE 100 index has no unit root and hence it has stationarity at $1^{\text {st }}$ difference. Therefore, at the $1^{\text {st }}$ difference equation 3 will be rewritten as:

$$
\begin{gathered}
\Delta Y t=x^{\prime} t+\beta 1 \Delta Y t-1+E T t \\
0.637130 .621803 \\
{[0.8450][9.61748]}
\end{gathered}
$$

Equation 4

At 1st difference, the failure in accepting the null hypothesis implies the presence of no unit root, confirms that the series is stationary at $1^{\text {st }}$ difference, while the findings at level and $1^{\text {st }}$ difference they both confirm that there is a real shocks in share prices $(\Delta \mathrm{Yt}-1)$ which explains the current fluctuation in Share prices $(\beta 1=$ $0.3829, \mathrm{t}=5.9142$ at level $; \beta 1=0.621803, \mathrm{t}=9.61748$ at $1^{\text {st }}$ difference $)$ but this real shock $(\Delta \mathrm{Y} t-1)$ is not

\begin{tabular}{|c|c|c|c|c|c|c|c|}
\hline At Level & & & & At $1^{\text {st }}$ Differe & & & \\
\hline & & t-Stats & Prob.* & & & t-Statistic & Prob.* \\
\hline ADF test & & & & ADF test & & & 0.0000 \\
\hline statistic & & 0.059153 & 0.9619 & statistic & & -16.34185 & \\
\hline Test Critical & & & & Test Critical & & & \\
\hline Values & $1 \%$ level & -3.457865 & & Values & $1 \%$ level & -3.457984 & \\
\hline & $\begin{array}{l}5 \% \text { level } \\
10 \%\end{array}$ & -2.873543 & & & $5 \%$ level & -2.873596 & \\
\hline & level & -2.573242 & & & $10 \%$ level & -2.573270 & \\
\hline
\end{tabular}
permanent and is only temporary since $\alpha=-0.00963$ at level, while, only $\alpha \geq 1$ implies the permanent shocks.

Table 2: Null Hypothesis: Money Supply (M2) has a unit root

The stationary level is also investigated in Money supply (M2). The empirical findings reveal that the money supply also has a unit root at level and hence it is a non stationary series at same order (i.e. ADF test statistics $=0.059153>$ critical values) like share prices, while stationarity is found present in M2 at $1^{\text {st }}$ difference (i.e. ADF test statistics= $0.059153>$ critical values). Since the ADF unit root test revealed in table 1 and table 2 that both the time series (i.e. share prices and money supply) have the stationarity at $1^{\text {st }}$ difference therefore it is found relevant to investigate, the interrelationships/ interdependence between both the time series via using vector auto-regression (VAR).

Table 3: Findings of Vector Auto Regression

$\Delta$ Share Prices OR $\Delta \mathrm{Y}$

\begin{tabular}{cc}
\hline$\Delta \mathrm{M} 2(-1)$ & $4.82 \mathrm{E}-06$ \\
& {$[1.83398]$} \\
$\Delta \mathrm{M} 2(-2)$ & $5.01 \mathrm{E}-06$ \\
$\Delta$ Share Prices $(-1)$ & {$[1.29144]$} \\
& 0.459253 \\
$\Delta$ Share Prices $(-2)$ & {$[6.18302]$} \\
C & -0.027173 \\
& {$[-0.35932]$} \\
R-squared & 0.391633 \\
Adj. R-squared & {$[0.51504]$} \\
Sum sq. resids & 0.167930 \\
S.E. equation & 0.149762 \\
F-statistic & 29857.92 \\
& 11.41858 \\
Log likelihood & 9.243427 \\
Durbin Watson & -902.6934 \\
\hline
\end{tabular}




$$
\begin{array}{clllll}
\Delta \mathrm{Yt}=\mathrm{C}+ & \beta 1 \Delta \mathrm{M} 2 \mathrm{t}-1+\beta 2 \Delta \mathrm{M} 2 \mathrm{t}-2+\beta 3 \Delta \mathrm{Y} \mathrm{t}-1+\beta 4 \Delta \mathrm{Y} 1-2+\mathrm{ETt} & \text { Equation } 5 \\
0.30163 & 4.82 \mathrm{E}-06 & -5.01 \mathrm{E}-06 & 0.45925 & -0.0271 & \\
{[0.515]} & {[1.84]} & {[1.29144]} & {[6.182]} & {[0.359]}
\end{array}
$$

The above findings translate that only fluctuation in money supply $(\Delta \mathrm{M} 2)$ for previous period and fluctuations in shares prices also for the same previous periods are significantly explaining to the fluctuations in Share prices of KSE 100 index for the current period, as the $\beta 1$ of $\Delta \mathrm{M} 2 \mathrm{t}_{\mathrm{t}-1}=4.82 \mathrm{E}-06$ at $\mathrm{t}=1.84$, while $\beta 3$ of $\Delta \mathrm{Y}_{\mathrm{t}-1}=0.45925$ at $\mathrm{t}=6.182$. The stated statistics revealed that the fluctuation in money supply for the very previous period i.e. a monetary shock explains the current fluctuations in Share prices of KSE 100 index very meagerly, while lag1 of change in shares prices also explaining the current fluctuation of the share prices which in short confirms the findings of unit root test.

Trend of Share Prices in relations with Money Supply (M2): Figure 1 reveals the trend of s Share prices of KSE 100 index in Pakistan. It suggested that Share prices of KSE 100 index with relation to the Money Supply rose in the beginning. It fell, and then again increased at the end. Trend of Share Prices in relations with M2 are showing growth with the span of time.

\section{Figure 1: Trend of Share Prices}

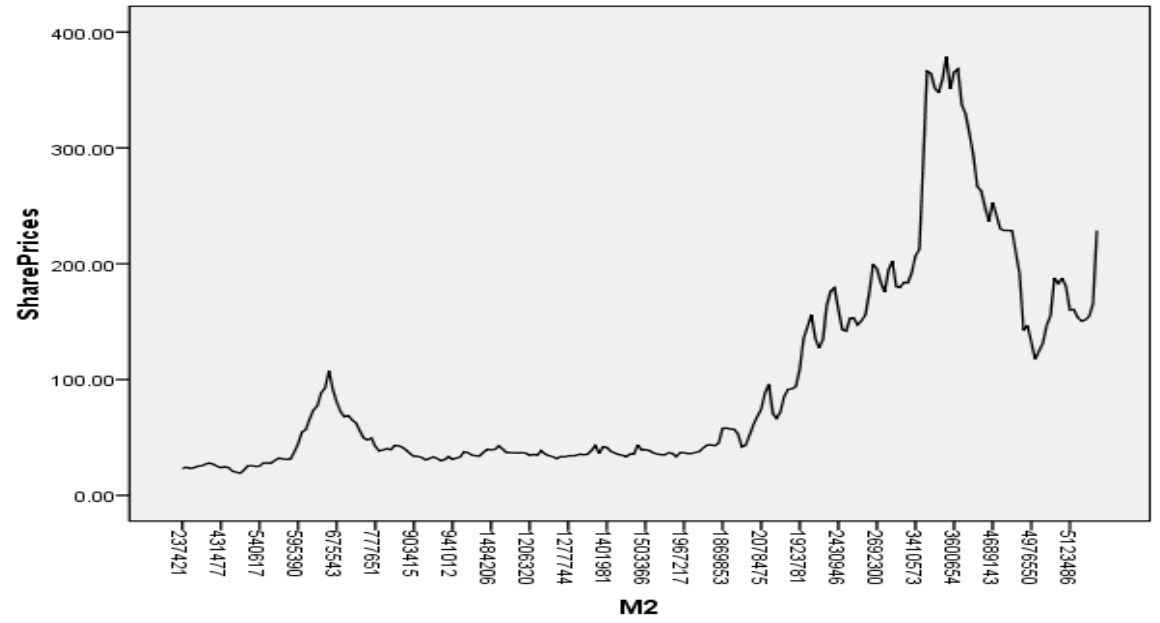

Table 4: Findings of Granger Causality Test

\begin{tabular}{lcc}
\hline Null Hypothesis: (Lag : 1) & F-Statistic & Probability \\
\hline M2 does not Granger Cause Share Prices of KSE 100 INDEX & 3.8974 & 0.0216 \\
Share Prices of KSE 100 INDEX do not Granger Cause M2 & 3.0432 & 0.0816
\end{tabular}

The first null hypothesis investigated through Granger causality test found rejected which explains that the past values of M2 do help in causing the current value of Share prices of KSE 100 index.

\section{Discussion and Conclusion}

This investigation focused on Money Supply and its fluctuations as the factors of oscillation in share prices in illumination of the recent volatility of Share prices of KSE 100 index in Pakistan. The stated oscillations and fluctuations which are so to speak as the bumps or the shocks are categorized as the real shocks (nonstationarity/ fluctuations in Share prices) and the monetary shocks (non- stationarity/ fluctuation in money supply) are the primary findings of this research. A unit root test, vector auto-regression, and Granger causality test were used to investigate the data and hypotheses. The applied econometrics provides the coincidental interaction of variables essential to the determination of share prices. The results are consistent with a direct impact of shifts in the money supply and shift in share prices for previous lags on the current 
changes in share prices (findings of VAR model for $\mathrm{H} 2$ and H3). This impact is significant, with a very previous lags that raises questions about the validness of the share market efficiency. It is important to mark that Hashemzadah and Taylor (1988) is in uniformity with the conclusion of this paper.

This reflection may indicate that aside from conflicts in the methodologies, the inefficiency of the share market may be an attribute of the recent years in distinction with the current sample period. The direct causal impact that the money supply has on share prices was observed in this study (the findings of Granger causality test for H4) can also be reinforced through the indirect channels suggested in theory. Some prospects of this indirect relationship supported in other studies like Pearce and Roley (1985) reported evidence on the causal unidirectional impact that the interest rate and money supply has on share prices. The failure in rejecting the null hypothesis/ or the failure in accepting the alternative hypothesis about the unit root in data of Share prices of KSE 100 index implies the presence of unit root, confirms that the series is a non-stationary series and also confirms that there is a real shocks in share prices $(\Delta \mathrm{Yt}-1)$ which explained the fluctuation in Share prices ( $\mathrm{b} 1=0.3829$ at $\mathrm{t}=5.9142$ ) but this real shock $(\Delta \mathrm{Yt}-1)$ is not permanent and is temporary since only a $\geq 1$ implies the permanent shocks (findings of Unit root test for H1). This relationship qualifies share prices to serve as a principal indicator of economic conditions as suggested by Fama (1981).

\section{Policy Implications}

Despite of the significant impact that monetary growth has on variations in share prices and the significance of these fluctuations on real activity, State Bank of Pakistan (SBP) officials have not regarded the change in share prices as a factor in their monetary policy design. The evidence of this study eulogizes to the following conclusion: SBP officials should develop the monetary policy by pondering on the stock market fluctuations and they require considering these fluctuations more formally if the stableness of real output growth extends to be a high priority item amongst the targets for monetary policy.

\section{References}

Alatiqi, S. \& Fazal, S. (2008). Can Money Supply predict Stock Prices? Journal for Economic Educators, 8(2), 5459.

Dhakal, D. \& Kandil, E. M. (1993). The Inflationary Experiences of Six Developing Countries in Asia: An Investigation of Underlying Determinants. Applied Economics, 25(3), 413-425.

Dhakal, D., Kandil, E. M. \& Sharma, S. (1993). Causality between money supply and share prices: A VAR investigation. Quarterly Journal of Business and Economics, 32(3), 52-74.

Fama, E., F. (1981). Stock Returns, Real Activity, Inflation and Money. American Economic Review, 71(4): 545565.

Fama, E., F. (1970). Efficient Capital Markets: A Review of Theory and Empirical Work. Journal of Finance, 25 (2), 383-417.

Hashemzadeh, N. \& Taylor, P. (1988). Stock Prices, Money Supply and Interest Rates: The Question of Causality, Applied Economics, 20(12), 1603-1611.

Homa, K,, E. \& Jaffe, D., M. (1971). The Supply of Money and Common Stock Prices. The Journal of Finance, 26(5), 1045-1066.

Kraft, J. \& Kraft, A. (1977). Determinants of Common Stock Prices: A Time Series Analysis. The Journal of Finance, 32(2), 417-425.

Mookerjee, R. (1987). Monetary Policy and the Informational Efficiency of the Stock Market: the Evidence from Many Countries. Applied Economics, 19, 1521-1532.

Pearce, D., K. \& Roley, V., V. (1985). Stock Prices and Economic News. Journal of Business, 58(1), 49-67.

Sprinkel, B., W. (1964). Money and Markets: A Monetarist View. Homewood, Illinois: Richard Irwin, Inc.

Subhani, M. I. \& Osman, A. (2010). Stock Market Reactions due to the announcements of Consumer Price Index and the Investigations of Endogeneity. Interdisciplinary Journal of Contemporary Research in Business, 3(1), 878-884. 